\title{
Effect of methacholine challenge on cellular composition of sputum induction
}

\author{
A Spanevello, A M Vignola, A Bonanno, M Confalonieri, E Crimi, V Brusasco
}

Fondazione Salvatore Maugeri, Clinica del Lavoro e della Riabilitazione, Tradate, Italy A Spanevello

Istituto di Fisiopatologia Respiratoria, CNR, Palermo, Italy A M Vignola A Bonanno

Divisione di Pneumologia, Ospedale di Piacenza, Italy

M Confalonieri

Cattedra di Fisiopatologia Respiratoria, Dipartimento di

Scienze Motorie e Riabilitazione, Università di Genova, Italy

E Crimi

V Brusasco

Correspondence to: Dr A Spanevello, Fondazione Salvatore Maugeri, Tradate (VA), Italy.

Received 5 June 1998 Returned to author 29 July 1998

Revised manuscript received 26 August 1998

8 September 1998 Via Roncaccio 16, 21049

Accepted for publication

\begin{abstract}
Background-Induced sputum and methacholine inhalation challenge are routinely used for the assessment of airway inflammation and airway hyperresponsiveness, respectively. This study investigates whether a methacholine challenge performed one hour before sputum induction alters the cellular and biochemical constituents of sputum.

Methods-Sixteen stable asthmatic patients with lung function within the normal range underwent two sputum inductions within one week. One hour before one of the sputum inductions a methacholine challenge was performed.

Results-There were no significant differences in total cell count, macrophages, neutrophils, eosinophils, lymphocytes, epithelial cells, ECP, and albumin between the two challenges. The repeatability of cell counts was good for all cells, ECP and albumin, but poor for total cells.

Conclusions-In patients with stable asthma a methacholine challenge carried out one hour before sputum induction does not significantly alter the cellular and biochemical constituents of sputum.

(Thorax 1999;54:37-39)
\end{abstract}

Keywords: asthma; methacholine challenge; induced sputum

Airway inflammation and airway hyperresponsiveness are characteristics of bronchial asthma. ${ }^{1}$ Airway hyperresponsiveness is frequently assessed by methacholine inhalation

Table 1 Characteristics of subjects

\begin{tabular}{lllrrr}
\hline Subject no. & $\begin{array}{l}\text { Age } \\
\text { (years) }\end{array}$ & Sex & $\begin{array}{c}P D_{20} \\
(\mu g)\end{array}$ & $\begin{array}{c}F E V^{*} \\
(\% \text { pred })\end{array}$ & $\begin{array}{c}\text { FEV } \\
(\% \text { pred })\end{array}$ \\
\hline 1 & 45 & $\mathrm{M}$ & 890 & 113 & 120 \\
2 & 23 & $\mathrm{~F}$ & 55 & 95 & 97 \\
3 & 47 & $\mathrm{~F}$ & 85 & 92 & 89 \\
4 & 45 & $\mathrm{M}$ & 170 & 110 & 114 \\
5 & 29 & $\mathrm{M}$ & 538 & 97 & 100 \\
6 & 33 & $\mathrm{~F}$ & 652 & 99 & 97 \\
7 & 24 & $\mathrm{~F}$ & 676 & 112 & 109 \\
8 & 18 & $\mathrm{~F}$ & 47 & 89 & 84 \\
9 & 23 & $\mathrm{~F}$ & 89 & 107 & 110 \\
10 & 40 & $\mathrm{~F}$ & 1039 & 95 & 98 \\
11 & 28 & $\mathrm{M}$ & 20 & 94 & 94 \\
12 & 56 & $\mathrm{~F}$ & 154 & 100 & 100 \\
13 & 31 & $\mathrm{~F}$ & 120 & 95 & 93 \\
14 & 39 & $\mathrm{M}$ & 770 & 105 & 109 \\
15 & 21 & $\mathrm{M}$ & 466 & 95 & 96 \\
16 & 39 & $\mathrm{M}$ & 219 & 89 & 88 \\
Mean & 33.8 & & & 99.2 & 99.9 \\
SD & 11.0 & & & 7.9 & 10.0 \\
Geometric mean & & & 215 & & \\
\hline
\end{tabular}

$\mathrm{FEV}_{1}{ }^{\star}=$ forced expiratory volume in one second performed prior to sputum induction on day without methacholine challenge.

$\mathrm{FEV}_{1}=$ forced expiratory volume in one second performed prior to methacholine challenge

$\mathrm{PD}_{20}=$ concentration of methacholine provoking a $20 \%$ reduction in $\mathrm{FEV}_{1}$. challenge. ${ }^{2}$ Airway inflammation can be assessed invasively by bronchoscopy or noninvasively by induced sputum. ${ }^{3-7}$ Because of the loose relationships between airway inflammation and airway hyperresponsiveness, ${ }^{8}$ these assessments may yield complementary information. In clinical studies it would be useful if airway inflammation and airway hyperresponsiveness could be measured at the same visit. To achieve this, methacholine challenge must precede sputum induction as sputum induction requires premedication with $\beta_{2}$ agonists. ${ }^{9}$

It is not known whether a methacholine challenge carried out before sputum induction alters the sputum cell count. This study compares the total and differential cell counts as well as the biochemical characteristics (ECP, albumin) of induced sputum obtained with or without a prior methacholine inhalation challenge.

\section{Methods}

SUBJECTS

Sixteen non-smoking subjects with bronchial asthma, defined as a clinical history of intermittent wheeze, cough, chest tightness, or dyspnoea, participated in the study (table 1). Subjects were taking only inhaled short acting $\beta_{2}$ agonists on an as needed basis for their asthma.

At the time of the study all subjects were in a stable clinical condition as demonstrated by the low daily variability $(<15 \%)$ of peak flow measurements during the two weeks before the study and by the low variability in forced expiratory volume in one second $\left(\mathrm{FEV}_{1}\right)$ performed in the two days of the study (table 1). All subjects had lung function within the normal range and methacholine airway responsiveness with the dose required to provoke a fall in $\mathrm{FEV}_{1}$ of $20 \%$ or more $\left(\mathrm{PD}_{20} \mathrm{FEV}_{1}\right)$ of $<1600 \mu \mathrm{g} .{ }^{10}$ Each subject attended the laboratory on two occasions within one week at least 48 hours apart. On one occasion, at random, sputum induction was performed one hour after methacholine challenge. The sputum induction was performed at the same time of the day on the two occasions.

The study was approved by the ethics committee of Fondazione Maugeri and all subjects gave written informed consent.

\section{METHACHOLINE CHALIENGE}

Methacholine (Sigma Chemicals Co, St Louis, Missouri, USA) was dissolved in distilled water and delivered by an ampoule dosimeter device (Mefar, Brescia, Italy) driven by compressed air at a pressure of $1.5 \mathrm{~kg} / \mathrm{m}^{2}$ with one second actuations and five second intervals between breaths. Aerosols were inhaled during quiet 
tidal breathing. After inhalation of isotonic saline as a control, doubling doses of methacholine were inhaled from 20 to $1600 \mu \mathrm{g}$. A three minute interval was allowed before each dose increment. $\mathrm{FEV}_{1}$ was measured one minute after each dose and the best of three acceptable measurements was retained to create dose-response curves. The non-cumulative $\mathrm{PD}_{20} \mathrm{FEV}_{1}$ values were calculated by interpolation between two adjacent points of the log dose-response curves.

SPUTUM INDUCTION

\section{Inhalation procedure}

After baseline $\mathrm{FEV}_{1}$ and forced vital capacity (FVC) measurements were taken, salbutamol was given by inhalation ( $200 \mu \mathrm{g}$ by MDI) and subjects inhaled hypertonic $(4.5 \%)$ saline nebulised for periods of progressively increasing length (1, 2, 4, 8, 16 minutes). $\mathrm{FEV}_{1}$ was again measured one minute after each inhalation period. Saline solutions were nebulised by an ultrasonic nebuliser (DeVilbiss 65, DeVilbiss Corp, Somerset, Pennsylvania, USA). On the methacholine challenge day salbutamol $(200 \mu \mathrm{g}$ by MDI) was given at the end of the challenge to hasten the recovery of lung function.

\section{Sputum processing}

The collected sputum samples were examined within two hours. Selected portions of the sputum sample originating from the lower respiratory tract were chosen using an inverted microscope and weighed. Dithiothreitol (DTT, Sputolysin, Calbiochem Corp, San Diego, California, USA), freshly prepared in a dilution of one in 10 with distilled water, was added in a volume (in litres) equal to four times the weight of the sputum portion (in $\mathrm{mg}$ ). Selected sputum was placed in a shaking water bath at $37^{\circ} \mathrm{C}$ for 20 minutes to ensure complete homogenisation. It was further diluted with phosphate buffered saline in a volume equal to the sputum plus DTT. The suspension was filtered through gauze to remove mucus and was centrifuged at $1000 \mathrm{~g}$ for five minutes. The supernatant was aspirated and frozen at $-70^{\circ} \mathrm{C}$ for later $\operatorname{ECP}(\mu \mathrm{g} / \mathrm{ml})$ and albumin $(\mu \mathrm{g} / \mathrm{ml})$ analysis by radioimmunoassay (RIA; Kaby Pharmacia Diagnostic AB, Uppsala, Sweden). The cell pellet was resuspended in a volume of PBS equal to that of the sputum plus DTT and PBS as above. Total cell count (TCC) and viability (Trypan blue exclusion method) were determined using a Burke's chamber haemocytometer. The cell suspension was placed in a Shandon 3 cytocentrifuge (Shandon Southern Instruments, Sewickley, Pennsylvania, USA) and cytospins were prepared at $450 \mathrm{rpm}$ for six minutes. Cytospin slides were fixed in methanol and stained with May-Grunwald Giemsa for an overall differential cell count of 500 nucleated non-squamous cells. Only samples with cell viability of $>50 \%$ and squamous cell contamination of $<20 \%$ were considered adequate. All subjects were able to produce an adequate sample on the two occasions. All sputum counts and measurements were performed blind to the clinical details.

\section{STATISTICAL ANALYSIS}

Descriptive statistics were used to summarise the clinical and demographic characteristics of the subjects. Data were reported as the arithmetic mean and standard deviation. $\mathrm{PD}_{20}$ data were $\log$ transformed and reported as geometric means. Wilcoxon signed rank tests were used to compare cell counts and biochemical markers of the two sputum samples. The repeatability of measurements was examined by the reliability coefficient (intraclass correlation coefficient $=\mathrm{R}$ ) as the proportion of the variance in the measures due to the true variance between subjects. Data are presented as median and interquartile range. A value of $\mathrm{p}<0.05$ was considered statistically significant.

\section{Results}

Total and differential cell counts with and without methacholine challenge are shown in table 2. There were no significant differences in total cell count, percentage or absolute numbers of sputum macrophages, neutrophils, eosinophils, lymphocytes, and epithelial cells with and without methacholine challenge.

Table 2 Induced sputum total and differential cell count and fluid analysis (ECP and albumin) when performed (A) without and (B) with methacholine challenge

\begin{tabular}{|c|c|c|c|c|c|c|c|c|c|c|c|c|c|c|c|c|}
\hline $\begin{array}{l}\text { Patient } \\
\text { no. }\end{array}$ & $\begin{array}{l}T C C \\
(A)\end{array}$ & $\begin{array}{l}\text { TCC } \\
\text { (B) }\end{array}$ & $\begin{array}{l}M a c \\
(A)\end{array}$ & $\begin{array}{l}\text { Mac } \\
\text { (B) }\end{array}$ & $\begin{array}{l}N e u \\
(A)\end{array}$ & $\begin{array}{l}\mathrm{Neu} \\
\text { (B) }\end{array}$ & $\begin{array}{l}\text { Eos } \\
(A)\end{array}$ & $\begin{array}{l}\text { Eos } \\
\text { (B) }\end{array}$ & $\begin{array}{l}\text { Lym } \\
(A)\end{array}$ & $\begin{array}{l}\text { Lym } \\
(B)\end{array}$ & $\begin{array}{l}\text { Epi } \\
(A)\end{array}$ & $\begin{array}{l}E p i \\
\text { (B) }\end{array}$ & $\begin{array}{l}E C P \\
(A)\end{array}$ & $\begin{array}{l}E C P \\
\text { (B) }\end{array}$ & $\begin{array}{l}A l b \\
(A)\end{array}$ & $\begin{array}{c}A l b \\
(B)\end{array}$ \\
\hline 1 & 800 & 1600 & 9.8 & 7.6 & 76 & 79.4 & 13.8 & 12.8 & 0.4 & 0 & 0 & 0.2 & & & 664 & 424 \\
\hline 2 & 80 & 384 & 15 & 22.4 & 83.5 & 76.4 & 1.5 & 0.4 & 0 & 0.4 & 0 & 0.2 & & & & \\
\hline 3 & 1680 & 880 & 64.8 & 33.6 & 12.4 & 16.4 & 18 & 42 & 1.2 & 0.4 & 3.6 & 7.6 & & & & \\
\hline 4 & 880 & 1840 & 22.6 & 18.4 & 76.2 & 80.2 & 1.2 & 1 & 0 & 0.2 & 0 & 0.2 & 624 & 142 & 232 & 136 \\
\hline 5 & 1280 & 2240 & 55.6 & 31.8 & 38.4 & 64.4 & 5.6 & 3.6 & 0.4 & 0 & 0 & 0.2 & 960 & 2080 & 1280 & 1776 \\
\hline 6 & 440 & 800 & 58.4 & 45.2 & 39.2 & 51 & 0.2 & 0.4 & 2 & 3.4 & 0.2 & 0 & & & & \\
\hline 7 & 320 & 128 & 57.6 & 49 & 40.4 & 49.6 & 0 & 0 & 1 & 0 & 1 & 1.4 & 40 & 33 & 120 & 40 \\
\hline 8 & 96 & 360 & 67.2 & 61.4 & 11.2 & 16.2 & 20.8 & 21 & 0 & 0 & 0.8 & 1.4 & & & & \\
\hline 9 & 160 & 280 & 81.8 & 80.8 & 15.6 & 14.8 & 2.4 & 3.2 & 0.2 & 0.6 & 0 & 0.6 & 480 & 608 & 120 & 320 \\
\hline 10 & 480 & 96 & 40.4 & 57.4 & 59.2 & 42 & 0 & 0.2 & 0 & 0 & 0.4 & 0.4 & 520 & 96 & 552 & 384 \\
\hline 11 & 640 & 336 & 55.2 & 50.4 & 41.4 & 45 & 3 & 4.2 & 0 & 0.4 & 0.4 & 0 & 976 & 1104 & 320 & 728 \\
\hline 12 & 480 & 240 & 62.4 & 51.4 & 28.8 & 42 & 7.2 & 5.6 & 1.6 & 0.8 & 0 & 0.2 & 1200 & 1520 & 224 & 632 \\
\hline 13 & 480 & 336 & 77.2 & 73 & 22 & 26.6 & 0.4 & 0 & 0.4 & 0.2 & 0 & 0.2 & & & & \\
\hline 14 & 336 & 880 & 29.4 & 26.4 & 69.2 & 72.8 & 0.8 & 0.4 & 0 & 0 & 0.6 & 0.4 & 600 & 416 & 152 & 216 \\
\hline 15 & 800 & 560 & 62.6 & 68 & 27.8 & 25.4 & 8.4 & 6.4 & 0 & 0 & 1.2 & 0.2 & & & & \\
\hline 16 & 312 & 536 & 42.6 & 44.2 & 5.6 & 3.6 & 51.6 & 52 & 0.2 & 0 & 0 & 0.2 & & & & \\
\hline Median & 480 & 460 & 56.6 & 47.1 & 38.8 & 43.5 & 2.7 & 3.4 & 0.2 & 0.1 & 0.1 & 0.2 & 612 & 512 & 232 & 384 \\
\hline Range & $80-1680$ & $96-2240$ & $9.8-81.8$ & $7.6-80.8$ & $5.6-83.5$ & $3.6-80.2$ & $0-51.6$ & $0-52$ & $0-1.6$ & $0-3.4$ & $0-3.6$ & $0-7.6$ & $40-1200$ & $33-2080$ & $120-1280$ & $40-1776$ \\
\hline Wilcoxon & $\mathrm{p}=0.32$ & & $\mathrm{p}=0.08$ & & $\mathrm{p}=0.06$ & & $\mathrm{p}=0.49$ & & $\mathrm{p}=0.69$ & & $\mathrm{p}=0.22$ & & $\mathrm{p}=1.0$ & & $\mathrm{p}=0.37$ & \\
\hline $\mathrm{R}$ & 0.56 & & 0.83 & & 0.93 & & 0.91 & & 0.71 & & 0.73 & & 0.66 & & 0.81 & \\
\hline
\end{tabular}

TCC $=$ total cell count $\left(\right.$ no. cells $\left./ \mathrm{ml} \times 10^{4}\right) ; \mathrm{Mac}=$ macrophages $(\%) ;$ Neu = neutrophils $(\%) ;$ Eos = eosinophils $(\%) ;$ Lym = lymphocytes $(\%) ;$ Epi $=$ epithelial cells (\%); $\mathrm{ECP}=\mu \mathrm{g} / \mathrm{ml} ;$ albumin $=\mu \mathrm{g} / \mathrm{ml} ; \mathrm{R}=$ coefficient of reliability. 
There was no significant difference between sputum cell viability with (median $79 \%$, range 59-88) and without (median 80\%, range 76-90) methacholine challenge. Again, no significant differences were noted in sputum ECP and albumin levels. The repeatability $(\mathrm{R})$ of cell counts was good for all cells, ECP and albumin, but poor for total cells.

\section{Discussion}

This study in asthmatic patients shows that a methacholine challenge carried out one hour before induction of sputum does not significantly alter the cellular and biochemical constituents of the sputum.

The effects of methacholine challenge on bronchoalveolar lavage (BAL) fluid cell count have been extensively evaluated in previous studies. Lam et al showed that a methacholine challenge performed 10 minutes before bronchoscopy did not alter significantly the BAL fluid cell counts. ${ }^{11}$ Beasley et al found that the numbers of nucleated cells in BAL fluid were increased 18 hours after methacholine challenge in asthmatic subjects. However, the percentages of each inflammatory cell type, such as lymphocytes, eosinophils, neutrophils and macrophages, were unchanged. ${ }^{12}$ In contrast, Soderberg et al found that neither cell count nor albumin concentration were changed in BAL fluid 24 hours after methacholine challenge. ${ }^{13}$ Although the results of BAL fluid and sputum studies cannot be directly compared, the results of the present study confirm that methacholine challenge does not alter significantly the assessment of airway inflammation. We believe our results may be helpful for both clinical purposes and for designing clinical trials in which information on airway inflammation and airway hyperresponsiveness is sought.

1 National Asthma Education Program Expert Panel Report. Overview of approaches to asthma therapy. In: Guidelines for the diagnosis and management of asthma. NIH Publication No. 91-3042. Bethesda, MD: Department of Health and Human Services.

2 Hargreave FE, Ryan G, Thomson NC. Bronchial responsiveness to histamine or methacholine in asthma: measurement and clinical significance. I Allergy Clin Immunol 1981;68:347-55

3 Pin I, Gibson PG, Kolendovicz R, et al. Use of induced spuum cell counts to investigate airway inflammation in asthma. Thorax 1992;47:25-9.

4 Fahy JV, Liu J, Wong $\mathrm{H}$, et al. Cellular and biochemical analysis of induced sputum from asthmatic and from

5 Spanevello A, Migliori GB, Sharara AM, et al. Induced sputum to assess airway inflammation: a study of reproducibility. Clin Exp Allergy 1997;27:1138-44.

6 In't Veen JCCM, De Gouw HWFM, Smits HH, et al. Repeatability of cellular and soluble markers of inflammation in induced sputum from patients with asthma. Eur Respir f 1996;9:2441-7.

7 Pizzichini E, Pizzichini MMM, Efthimiadis A, et al. Indices of airway inflammation in induced sputum: reproducibility and validity of cell fluid-phase measurements. Am $\mathcal{F}$ Respir Crit Care Med 1996;154:308-17.

8 Crimi E, Spanevello A, Neri M, et al. Dissociation between airway inflammation and airway hyperresponsiveness in allergic asthma. Am f Respir Crit Care Med 1998;157:4-9.

9 Wong HH, Fahy JV. Safety of one method of sputum induction in asthmatic subjects. Am F Respir Crit Care Med 1997; 156:299-303.

10 Quanjer PH, ed. Report of Working Party of European Community for Coal and Steel. Standardization of lung function tests. Bull Eur Physiopathol Respir 1983;19(Suppl 5):7-87.

11 Lam S, Al-Majed S, Chan H, et al. Differences in mediator release between allergic rhinitis and asthma. $\mathcal{F}$ Allergy Clin Immunol 1991;87:842-9.

12 Beasley R, Roche WR, Roberts JA, et al. Cellular events in the bronchi in mild asthma and after bronchial provocation. Am Rev Respir Dis 1989;139:806-17.

13 Soderberg M, Lundgren R, Bjermer L, et al. Inhaled methacholine does not influence the cellular composition of bronchoalveolar lavage fluid. Allergy 1993;48:173-6. 